\title{
Religiosity and Entrepreneurship: A Systematic Review and Future Research Lines
}

\author{
ALHAWITI HISSAH MUSALLAM ${ }^{1}$, SUZILAWATI KAMARUDIN ${ }^{2}$ \\ ${ }^{1}$ Azman Hashim International Business School, UNIVERSITI TEKNOLOGI MALAYSIA, MALAYSIA. \\ E-mail: hissah35@gmail.com \\ ${ }^{2}$ College of Business Administration, UNIVERSITY OF BUSINESS AND TECHNOLOGY, Jeddah, KSA. \\ ${ }^{2}$ Azman Hashim International Business School, UNIVERSITI TEKNOLOGI MALAYSIA, MALAYSIA. \\ E-mail: s.kamarudin@ubt.edu.sa, suzilawati@ibs.utm.my
}

\begin{abstract}
The literature on religiosity and entrepreneurship is fragmented, and yet, this concept hardly discussed by scholars in terms of integrating the available studies. The purpose of this study is to provide systematic review of contributions related to religiosity and entrepreneurship, and propose future research lines. The synthesis of literature evaluates research studies that are covered in the Web of Science index. This study provides grey areas that need to explore further by connecting dots between religiosity and entrepreneurship using theoretical integration, methodological and empirical investigation. A new research avenue arises for both empirical and conceptual by highlighting religiosity as a driving force for entrepreneurial activity. Future research lines can examine the effectiveness of different type of temporal collaboration approach under shed of religiosity principals in an entrepreneurial ecosystem. In addition, this review provides opportunity to scholars, academicians and practitioners a better understanding of the religiosity value and link with entrepreneurship.
\end{abstract}

Keywords: Entrepreneurship; Religiosity; Literature Review

JEL Classification: Z1, Z120, D2

Recibido: 23 de Noviembre de 2020

Aceptado: 2 de Marzo de 2021 


\section{Introduction}

Religiosity is an important characteristic that defines meaning and purpose of the life (Damiano et al., 2017). A robust body of knowledge gave scholarly attention to impact of religiosity on world view (Ritchie, 2016), attitudes, behaviour (Johnson et al., 2013), work habits, economic actions, approaches to business, and general life (Weber, 1992; Deutschmann, 2003; Neal, 2013). Religiosity is always linked to values, morality and ethics. Religions are often the source of values as well as morality for their followers. In a broad sense, religiosity refers to symbols, doctrines, beliefs, prescriptions, values and norms that guide one's life. Religion and religiosity manifest themselves in various forms and ways. Religion and religiosity are expected to motivate followers in terms of their entrepreneurial behaviours (Adamu and Mansur, 2018). Despite the centrality of religion to most of their followers, not many studies have investigated the relationship between religion and business performance. Zahrah et al. (2016) found that religion significantly influence business performance. The two concepts of entrepreneurship and religiosity are often associated with each other. The relationship between the two has been largely overlooked by scholars in the area of entrepreneurship. Religiosity in the context of management and entrepreneurship is defined as the extent to which to which an entrepreneur / employee believes in and/or venerates the founder, gods or goddesses of the relevant religion, practices the religion and participate in the activities expected of the followers of the religion in question (Iddagoda and Opatha, 2017). In the context of this research and Saudi Arabia where the entire country's population adhere to the Islamic faith, religion can be defined as the extent to which an entrepreneur believes in Allah, practices the teachings of Islam and participate in the activities expected of Muslims and recommended by the Islamic faith. When trying to understand individual's in relation to entrepreneurship, religion is a concept that can be critical in understanding such intricate relationship.

According to Max Weber's school of thought, religiosity is the main driving force behind entrepreneurship because people are product of religious values (Weber, 1992). This is in line with the findings of Henley (2017) stating that religiosity significantly impacts entrepreneurship. The impact of religion on entrepreneurship might be productive or unproductive. Additionally, various religions have different perspectives about entrepreneurship (Neal, 2013; Deller et al., 2018). For instance, some religions may encourage wealth accumulation, while some others perceive it as materialistic. Adherents of the religion that values wealth accumulation may have more inclination to entrepreneurial activities (Wiseman and Young, 2014). According to Audretsch and Belitski (2013), Muslims and Jains are more likely to exhibit self-employed behavior than Hindus and Buddhists. Faizal et al. (2013) found that Islamic values encourage entrepreneurship, while Audretsch and Belitski (2013) found evidence that Christians are more inclined to be paid employees. Baharun and Kamarudin (2001) stated that religion appears to play an important role in the perceptions and business practices of business managers and entrepreneurs. Kamarudin et al (2013) argued that religious faith and liberalism have a different impact on entrepreneurs' values, strategy and business performance. The impact of religion on entrepreneurship can be investigated in different levels.

Notably, the available studies of religiosity and entrepreneurship are still few and fragmented, especially in the management sciences. Furthermore, the empirical investigation of religiosity values influence on entrepreneurial attitude, intention and behavior remains eclipse in the academic literature. Hence, the systematic review of literature presents the value significance of religiosity in the field of entrepreneurship. Thus, the dearth of literature discussed about to what extent nascent and experienced entrepreneurs give weightage to religiosity while doing entrepreneurial activity. This study provides direction to researchers from entrepreneurship field to study the religiosity construct as antecedent, mediator and moderator. In order to assess the religiosity, it is important to identify its main drivers. Practically, it is essential to know whether entrepreneurs pay worthy attention to religiosity when they intend to collaborate with each other. By mapping what is known, this review will be providing insights or the comprehensive view of prospects for future research in religiosity and entrepreneurship which is increasingly important field of studies. This study pursued to answer the 
research questions: 1) Which areas of religiosity and entrepreneurship research have been conducted in? 2) What methods are being used to research religiosity aspects and entrepreneurship? 3) What theories and type of studies utilized to research religiosity and relatedness with levels of entrepreneurial process? 4) What are the theoretical and empirical research gaps in identifying the relationship between religiosity and entrepreneurship?

This paper contributes in the following way: First, conducting desk research on the Web of Science (WoS) to study published work on topic religiosity and entrepreneurship; second, identifying the factors that discussed in scholarly work related to religiosity value composition and entrepreneurship. In this sense, this paper presents a deeper view of religiosity and entrepreneurship studies. The subsequent section provides research methodology used for systematic review, results extracted from literature analysis, depicts frequency-related findings, discussion and future research lines. Last section presents a succinct conclusion.

\section{Research Methodology}

The research methodology of systematic review of literature review is mentioned in several stages. Authors described protocol development, inclusion and exclusion criteria, and database search strategy in the sub-sequent sections.

\subsection{Protocol development}

The first step to perform systematic review is based on the protocol development for each phase. This study followed Cochrane Handbook for Systematic Reviews of Intervention as a guide to establish the protocols (Higgins and Green, 2008). The protocol development is aligned with the research objectives, which is synthesizing and evaluating the past studies on religiosity and entrepreneurship and its association within theoretical framework. This study used criteria of inclusion and exclusion for the selection of papers from web of science. The search strategy implemented with support of coding frame suggested on web of science. The categorization and quality assessment were performed on the basis of the objective of study. The aim of literature review is to know the factors that fall within the domain of religiosity principals and may influence on the entrepreneurship in various fields. In order to achieve this, authors used various criteria to categorized papers, as described in the analysis.

\subsection{Inclusion, Exclusion, and Search Strategy}

This study used relevant papers those published in the highly ranked journals from 1970 until April 2020. It is more important to delimit the review scope and validate the procedures. Thus, this study applied an iterative procedure to gather most relevant papers. This study used most comprehensive Core Collection database of Web of Science. The database search limit to three index name Arts \& Humanities Citation Index, Social Science Citation Index and Science Citation Index. Three database index were excluded form search named Book Citation Index, The Conference Proceedings Citation Index and Emerging Sources Citation Index. Type of document were selected as articles and reviews. Authors used one keyword to find the relevant papers in April 2020: "religiosity" AND "entrepreneurship". The initial search showed 16 articles which indexed by Scopus and ISI. After review the study title and abstract, two papers were excluded considering the aim of study and research objective. The exclusion of paper based on the irrelevancy to religiosity within entrepreneurship. Only papers discussed about religiosity and entrepreneurship were included for analysis and categorization. In total, 14 papers were selected. After that, content analysis was performed keeping in view the main focus on the concept of the articles (Webster and Watson, 2002, Khan \& Qureshi, 2020). The next phase is to perform coding as per the various criteria. In this sense, validity and reliability of article coding was evaluated by authors by doing initial screening. Hence, all 14 articles were ensured the compatibility related to the study topic i.e. religiosity and entrepreneurship. In terms of citation probability, authors develop a corpus of the contributions. It passed through meticulous review processes and having greater impact to future research studies in similar discipline. The findings are 
not subject to polysemy in terms of difference in study contexts. Consequently, this study aims to jot down the findings which progress in understanding religiosity and entrepreneurship. The findings are intended to sum up the past research work and give advantage to future work by considering the stringent assurance procedure of this study. The papers selected for review comprise of (Aygun et al., 2008; Wiseman and Young, 2014; Maniyalath and Narendran, 2016; Hoogendoorn et al, 2016; Dionigi, 2016; Gursoy et al, 2017; Liu et al., 2018; Baranik et al., 2018; Blankson et al., 2018; Toledano, 2019; Daou et al., 2019; Aman, 2019; Craciun, 2019; Woodside et al., 2020).

\section{Analysis of Studies}

\subsection{Categorization of Publications Based on the WoS}

Papers distribution by Web of Science category depicts in the Figure 1. As earlier mentioned, this study used Web of Science databases to identify papers. As per Figure 1 shows, 8 out of 14 papers are related to business, economic and social categories; two papers are related to psychology and anthropology; and four papers are covered in other disciplines. The findings indicated that dearth of articles related to religiosity and entrepreneurship. Based on the categorization, it is observed that religiosity aspect is hardly focused in the entrepreneurship research. Therefore, future research studies can focus on religiosity as an antecedent, mediator, moderator and predictor of entrepreneurial activity.

Figure 1. Papers distribution by Web of Science category

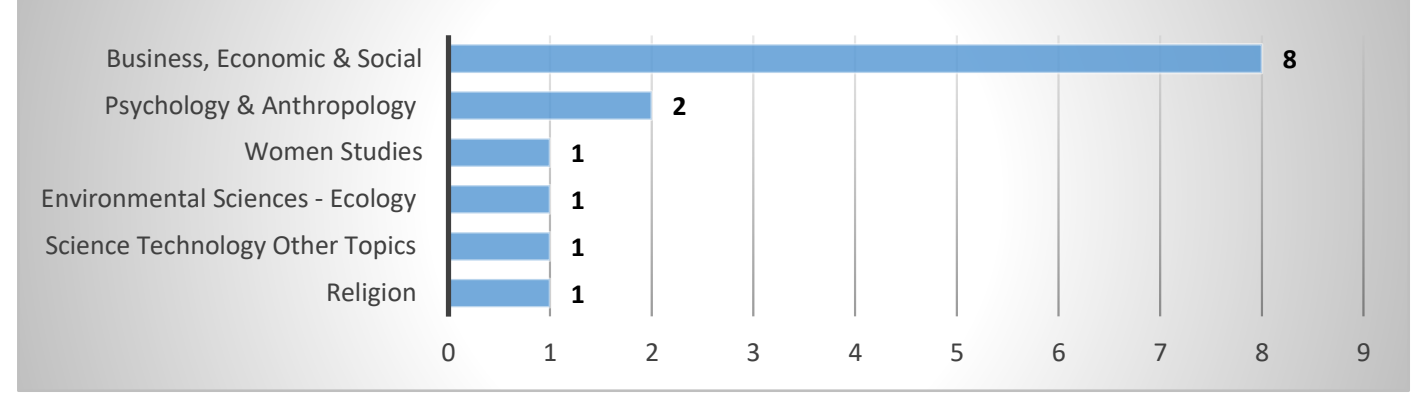

\subsection{Year of Publication, Citations, and Publication Outlet}

The distribution of selected papers by publication year depicts in the Figure 2 . The topic of religiosity and entrepreneurship garnered the major consideration in 2019, while limited number of studies published from 2016-2018. Notably, one study published in 2008 and 2014. Hence, the trend line is indicating that scholars have not worthy pay attention to examine religiosity with entrepreneurship. Until April 2020, only one study published as per the Web of Science database. However, more publications are still needed in management, business and social science.

Figure 2. Papers distribution by publication year

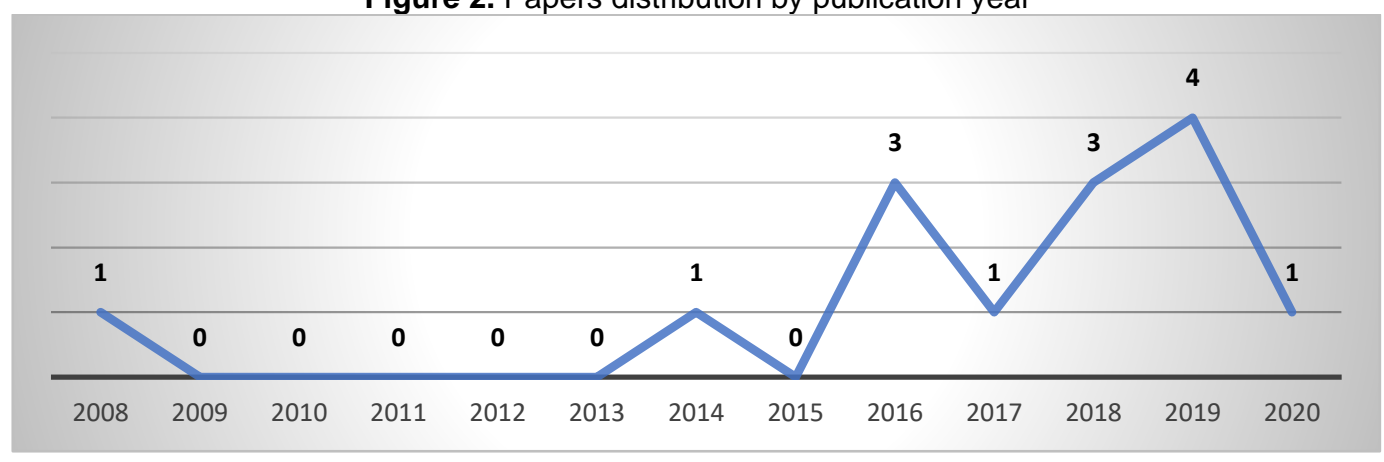


Figure 3. Citation per year of selected papers

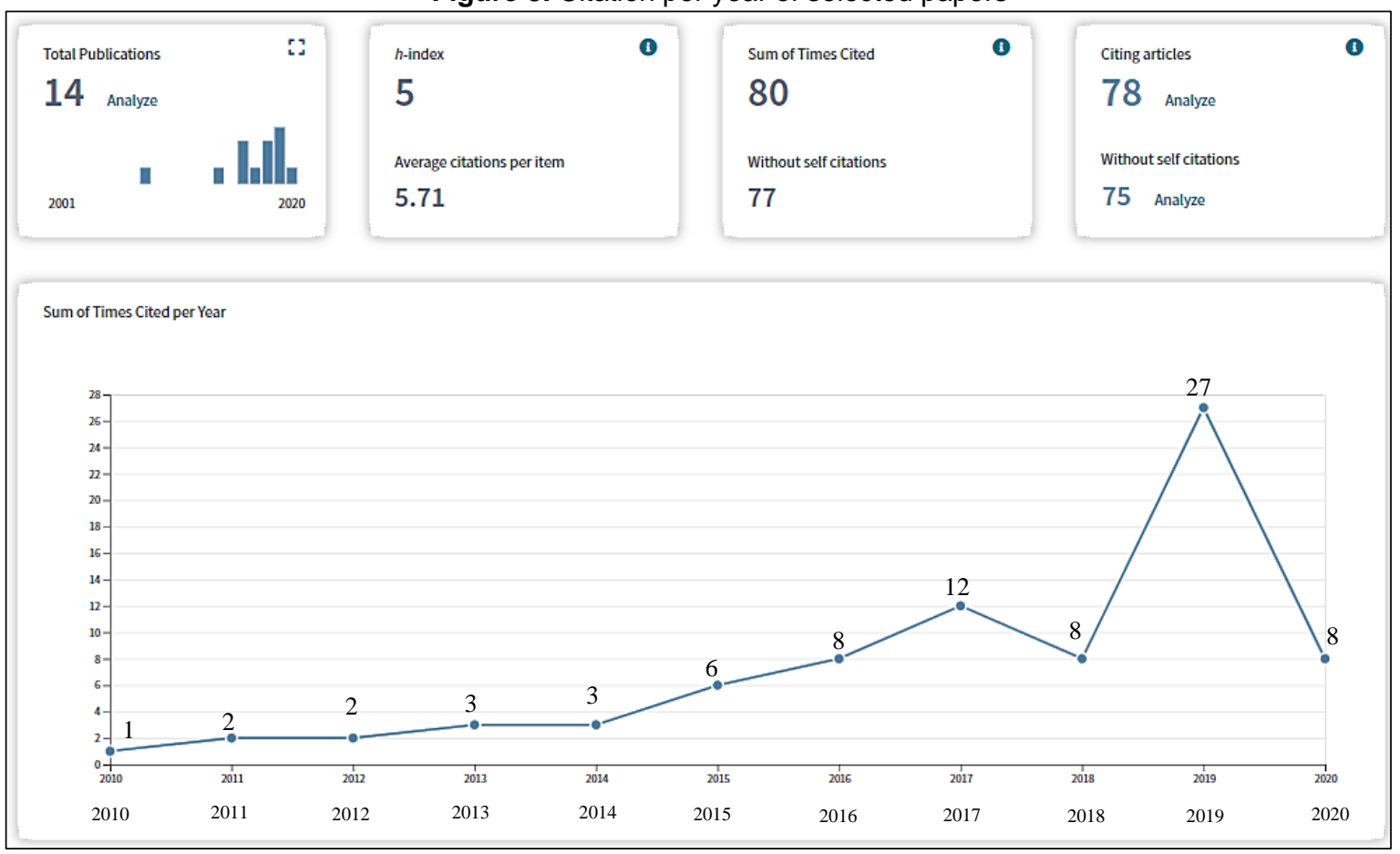

Figure 3 illustrates the sum of times cited per year for the selected papers. It also indicated the hindex and average citations per item. In total, 14 papers were cited 80 times in which 77 times without self-citations. Maximum number of citations reported in 2019 which is 27. As per the Web of Science database, first paper published on religiosity and entrepreneurship in 2008 and cited in 2010. From 2015 , the citations increased at minor scale but still need greater attention of scholars to study the concept of religiosity and entrepreneurship. The number of citations is increased as the publication increased in 2016 and onwards. As the number of papers increases, the field receives more attention, and more citations are recorded as a result of its greater popularity. For conciseness purpose, the individual citations for each paper per year in not mentioned here. In sum, 8 out of 14 papers cited over the time. Aygun et al., (2008) paper title "Work values of Turkish and American university students" received 31 citations over the time. Gursoy et al., (2017) paper title "Religiosity and entrepreneurship behaviours" cited 13 times till date.

Wiseman et al., (2014) paper title "Religion: productive or unproductive?" cited 12 times. The ratio of average citations per item is 5.71 , hence cumulative average per year 1.685 . This trend depicts the popularity of religiosity concept along with entrepreneurship in the literature.

Table 1 depicts the publications in journals since 2008. Of the 14 papers, all papers published in the different journals. From 2009 to 2013 and 2015, no publication recorded subject to topic religiosity and entrepreneurship. This indicates that scholars have not focused much on this topic. Although, published studies lacked in describing the role of religiosity towards entrepreneurial activity, entrepreneur attitude, intention and behavior. 
Table 1. Publications in journal

\begin{tabular}{|c|c|c|c|c|c|c|c|c|c|c|}
\hline \multirow{2}{*}{ Journal name } & \multicolumn{10}{|c|}{ Number of publications } \\
\hline & 2008 & $\ldots$ & 2014 & 2015 & 2016 & 2017 & 2018 & 2019 & 2020 & Total \\
\hline Journal of Business Ethics & 1 & & & & & & & & & 1 \\
\hline Journal of Institutional Economics & & & 1 & & & & & & & 1 \\
\hline Journal of Evolutionary Economics & & & & & 1 & & & & & 1 \\
\hline Politics and Religion & & & & & 1 & & & & & 1 \\
\hline $\begin{array}{c}\text { International Journal of } \\
\text { Entrepreneurial Behaviour \& } \\
\text { Research }\end{array}$ & & & & & 1 & & & & & 1 \\
\hline $\begin{array}{c}\text { International Journal of Hospitality } \\
\text { Management }\end{array}$ & & & & & & 1 & & & & 1 \\
\hline Journal of Macromarketing & & & & & & & 1 & & & 1 \\
\hline Sex Roles & & & & & & & 1 & & & 1 \\
\hline Frontiers in Psychology & & & & & & & 1 & & & 1 \\
\hline $\begin{array}{c}\text { International Entrepreneurship and } \\
\text { Management Journal }\end{array}$ & & & & & & & & 1 & & 1 \\
\hline Journal of Intellectual Capital & & & & & & & & 1 & & 1 \\
\hline Sustainability & & & & & & & & 1 & & 1 \\
\hline Ethnos & & & & & & & & 1 & & 1 \\
\hline $\begin{array}{l}\text { Journal of Business \& Industrial } \\
\text { Marketing }\end{array}$ & & & & & & & & & 1 & 1 \\
\hline Total per year & 1 & 0 & 1 & 0 & 3 & 1 & 3 & 4 & 1 & 14 \\
\hline
\end{tabular}

\subsection{Theory Focus}

Figure 4. Theories used in the published studies

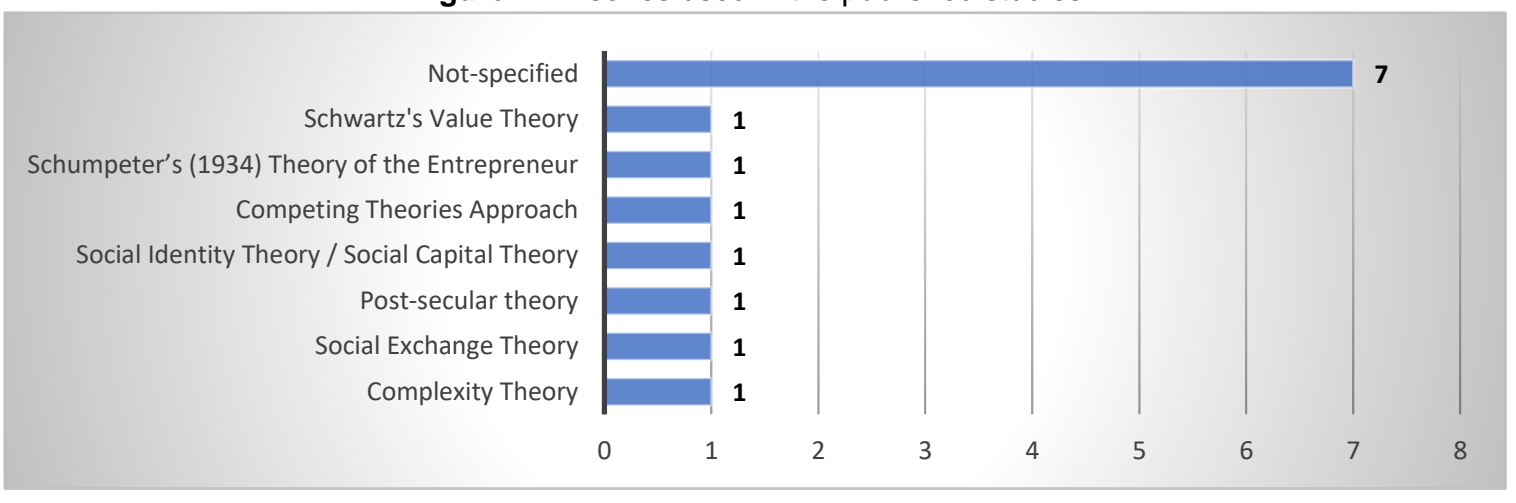

To improve a profound understanding of religiosity and entrepreneurship literature, a descriptive analysis was conducted in order to conduct this study. This study categorized 14 articles based on theoretical underpinning and relationship between religiosity and entrepreneurship. Theoretical support is necessary in terms of establishing the concept. It further elaborates the process of systematically developing the idea that empirically testable. In this sense, theory categorization used by scholars in the past studies will help future researchers to grasp the ideas where it comes from and examine it from multiple perspective. In other words, theory has capacity to conduct new research and produce new literature. Figure 4 depicts the theories used in the published studies. Despite the facts, majority of the papers have not specified any theory in the paper. Moreover, there is no repetition of theory in the rest of the papers. Hence, 7 out 14 papers used different theories subject to the scope of the study. Mainly conceptual papers do not reflect theory but main focus towards 
identifying the gap and future research lines. However, theories lapse in defining the framework for religiosity and entrepreneurship. Figure 5 indicates the type of study conducted in the selected papers.

Figure 5. Type of studies of selected papers from Web of Science

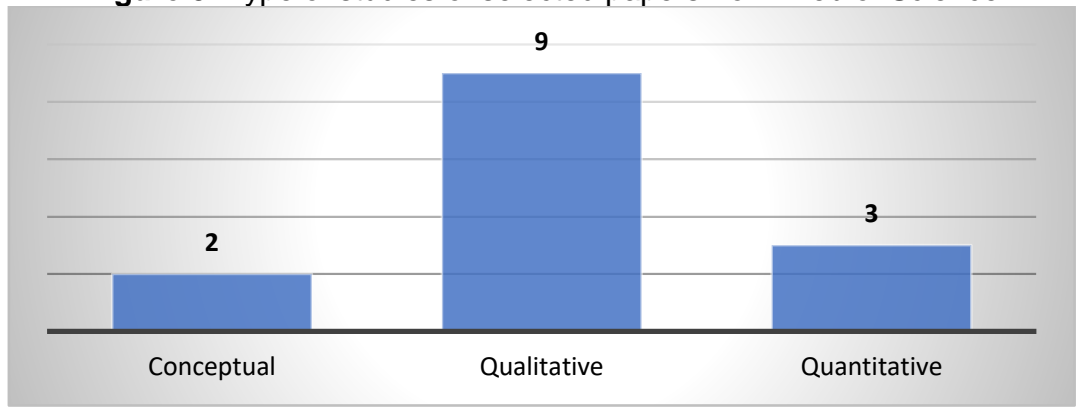

\subsection{Country focus}

This study used World Bank classification to categorized the countries (World Bank, 2020). The results mentioned in the Figure 6 indicated that two papers have not specified any country due to conceptual papers. There is no paper published from low income countries as per the Web of Science database. Four papers used multi-country analysis approach based on the secondary data analysis. In total six papers published from lower and upper middle income countries. Notably, only one paper published from high income country. These findings indicate that working on religiosity and entrepreneurship in middle income countries has more contribution, which includes five countries known as Iraq, Pakistan, Turkey, Tunisia and Ghana. Thus, the key findings indicated that scholars should emphasis on the more country in order to provide multiple perspective on religiosity and entrepreneurship.

Figure 6. Country focus distribution of papers

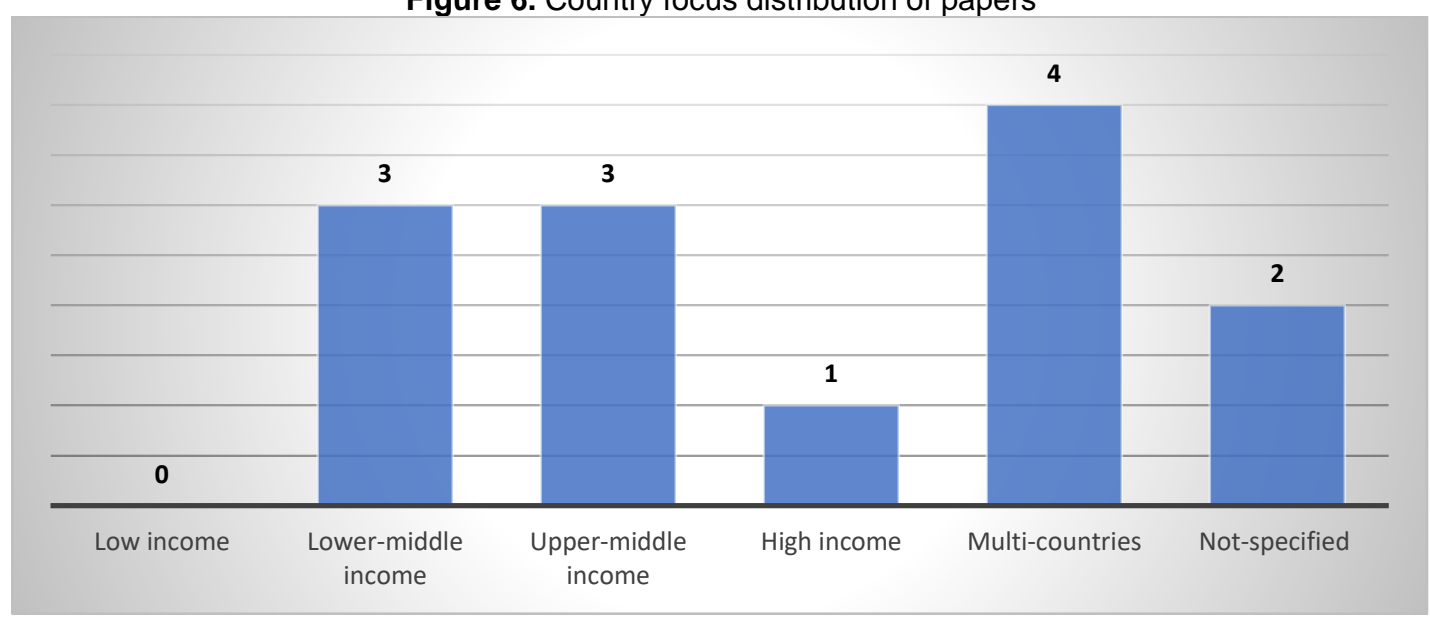

\subsection{Structuring the Contribution of published papers}

This systematic review of literature provides a future research lines in order to establish the relationship between religiosity and entrepreneurship. It can further help researchers to understand the role of religiosity in performing entrepreneurial activity, attitude, intention and behavior. It will be supportive to have a brief explanation of these terminologies. Table 2 indicates the brief review of 14 papers published related to religiosity and entrepreneurship.

Notably, religiosity is identified as an important indicator towards entrepreneurship. Although, different set of measures used to show the influence of religiosity on entrepreneurship. Hoogendoorn et al (2016) mentioned two aspect of religiosity. Internal religiosity linked to believing and behaving. External religiosity based on the belonging and bonding. In terms of business ownership, internal religiosity has positive effect on entrepreneurial activity. Gursoy et al (2017) presented the new perspective related to practicing and non-practicing Muslim entrepreneurs. It indicates that good 
practicing Muslim keep best practices for religiosity in order to perform entrepreneurial activities as compare to non-practicing Muslim entrepreneurs. Woodside et al (2020) argued that religiosity depicts ethical behavior of entrepreneur. Nonetheless, future research studies need to focus on the relative dimension of religiosity if in case leave effect as a predictor, mediator and moderator. Hence, there is still need to learn how to measure religiosity in social and business management sciences, beyond its exploratory assessment. In sum, 12 out of 14 papers established the link between religiosity and entrepreneurship, however, all of them depict diverse scope of study and technical aspect of the findings. There is less similarity among all the published studies extracted from Web of Science database. Hence, it provides opportunity for researcher to investigate religiosity as an important indicator subject to regional and demographic settings.

Table 2. Review of papers published by Web of Science database

\begin{tabular}{|c|c|c|c|c|}
\hline No & Author & Title & Year & Findings \\
\hline 1 & $\begin{array}{l}\text { Woodside, Arch G.; } \\
\text { Megehee, Carol M.; } \\
\text { Isaksson, Lars; } \\
\text { Ferguson, Graham }\end{array}$ & $\begin{array}{l}\text { Consequences of national } \\
\text { cultures and motivations on } \\
\text { entrepreneurship, } \\
\text { innovation, ethical behavior, } \\
\text { and quality-of-life }\end{array}$ & 2020 & $\begin{array}{c}\text { Religiosity indicates high in ethical } \\
\text { behavior, culture values and need } \\
\text { motivations individually }\end{array}$ \\
\hline 2 & Toledano, Nuria & $\begin{array}{l}\text { Looking for god, meaning, } \\
\text { physical fitness and beyond: } \\
\text { the religious and spiritual } \\
\text { space in sport } \\
\text { entrepreneurship }\end{array}$ & 2019 & $\begin{array}{l}\text { Sport entrepreneurship is re-thought } \\
\text { from its religious and spiritual } \\
\text { dimensions. Entrepreneurs' } \\
\text { religiosity/spirituality drives their } \\
\text { lifestyle entrepreneurship. }\end{array}$ \\
\hline 3 & $\begin{array}{l}\text { Daou, Alain; Joseph, } \\
\text { Jay; Yousif, Dalia } \\
\text { Sabah; Fathallah, } \\
\text { Ramzi; Reyes, Gerald }\end{array}$ & $\begin{array}{l}\text { Intellectual capital and } \\
\text { resilience in torn societies }\end{array}$ & 2019 & $\begin{array}{l}\text { Religiosity is an important aspect for } \\
\text { entrepreneurs. This indicates that } \\
\text { faith and religiosity play an important } \\
\text { role during hard times since they } \\
\text { encourage entrepreneurs not to lose } \\
\text { hope, have power, be patient, trust } \\
\text { God and count on God's will to } \\
\text { survive during turbulent times }\end{array}$ \\
\hline 4 & $\begin{array}{l}\text { Aman, Jaffar; Abbas, } \\
\text { Jaffar; Mahmood, } \\
\text { Shahid; Nurunnabi, } \\
\text { Mohammad; Bano, } \\
\text { Shaher }\end{array}$ & $\begin{array}{c}\text { The Influence of Islamic } \\
\text { Religiosity on the Perceived } \\
\text { Socio-Cultural Impact of } \\
\text { Sustainable Tourism } \\
\text { Development in Pakistan: A } \\
\text { Structural Equation Modeling } \\
\text { Approach }\end{array}$ & 2019 & $\begin{array}{l}\text { Higher religiosity level has a positive } \\
\text { attitude towards developing } \\
\text { sustainable tourism development }\end{array}$ \\
\hline 5 & Craciun, Magdalena & $\begin{array}{l}\text { A Seller's Sincerity: The } \\
\text { Fashionably Veiled } \\
\text { Designer-Entrepreneur in } \\
\text { Turkey }\end{array}$ & 2019 & $\begin{array}{l}\text { Religiosity plays an integral role for } \\
\text { fashionably veiled designer } \\
\text { entrepreneur in Turkey }\end{array}$ \\
\hline 6 & $\begin{array}{l}\text { Blankson, Charles; } \\
\text { Cowan, Kirsten; } \\
\text { Darley, William K. }\end{array}$ & $\begin{array}{c}\text { Marketing Practices of Rural } \\
\text { Micro and Small Businesses } \\
\text { in Ghana: The Role of Public } \\
\text { Policy }\end{array}$ & 2018 & $\begin{array}{l}\text { Rural micro and small businesses } \\
\text { weave morality and religiosity into } \\
\text { their commercial activities and survive } \\
\text { in a competitive subsistence } \\
\text { marketplace }\end{array}$ \\
\hline 7 & $\begin{array}{l}\text { Baranik, Lisa E.; } \\
\text { Gorman, Brandon; } \\
\text { Wales, William J. }\end{array}$ & $\begin{array}{l}\text { What Makes Muslim Women } \\
\text { Entrepreneurs Successful? } \\
\text { A Field Study Examining } \\
\text { Religiosity and Social Capital } \\
\text { in Tunisia }\end{array}$ & 2018 & $\begin{array}{c}\text { Examined the relationship between } \\
\text { religiosity and social capital among } \\
\text { Muslim women entrepreneurs in } \\
\text { Tunisia }\end{array}$ \\
\hline 8 & $\begin{array}{c}\text { Liu, Zhen; Guo, } \\
\text { Qingke; Sun, Peng; } \\
\text { Wang, Zhao; Wu, Rui }\end{array}$ & $\begin{array}{l}\text { Does Religion Hinder } \\
\text { Creativity? A National Level } \\
\text { Study on the Roles of } \\
\text { Religiosity and Different } \\
\text { Denominations }\end{array}$ & 2018 & $\begin{array}{l}\text { National religiosity hinders creativity } \\
\text { to a certain extent. However, some } \\
\text { denominations (i.e., Protestant and } \\
\text { Catholic) may exert positive } \\
\text { influences on creativity due to their } \\
\text { religious traditions and values. The } \\
\text { religion-creativity relationship at }\end{array}$ \\
\hline
\end{tabular}




\begin{tabular}{|c|c|c|c|c|}
\hline No & Author & Title & Year & Findings \\
\hline & & & & $\begin{array}{l}\text { national level only emerges in affluent } \\
\text { countries. }\end{array}$ \\
\hline 9 & $\begin{array}{l}\text { Gursoy, Dogan; } \\
\text { Altinay, Levent; } \\
\text { Kenebayeva, Ainur }\end{array}$ & $\begin{array}{l}\text { Religiosity and } \\
\text { entrepreneurship behaviors }\end{array}$ & 2017 & $\begin{array}{l}\text { Association between religiosity and } \\
\text { entrepreneurship behaviors. } \\
\text { Practicing Muslim entrepreneurs have } \\
\text { more respect for, commitment to and } \\
\text { acceptance of the religious and } \\
\text { traditional customs and ideas } \\
\text { compared with those non-practicing } \\
\text { Muslim entrepreneurs }\end{array}$ \\
\hline 10 & $\begin{array}{l}\text { Hoogendoorn, Brigitte; } \\
\text { Rietveld, Cornelius A.; } \\
\text { van Stel, Andre }\end{array}$ & $\begin{array}{l}\text { Belonging, believing, } \\
\text { bonding, and behaving: the } \\
\text { relationship between religion } \\
\text { and business ownership at } \\
\text { the country level }\end{array}$ & 2016 & $\begin{array}{l}\text { A positive relationship between } \\
\text { religion and business ownership } \\
\text { based on those dimensions that } \\
\text { reflect the internal aspects of } \\
\text { religiosity (i.e., believing and } \\
\text { behaving) and non-significant } \\
\text { relationship for external aspects of } \\
\text { religion (i.e., belonging and bonding) }\end{array}$ \\
\hline 11 & Dionigi, Filippo & $\begin{array}{l}\text { Dag Hammarskjold's } \\
\text { Religiosity and Norms } \\
\text { Entrepreneurship: A Post- } \\
\text { secular Perspective } \\
\end{array}$ & 2016 & $\begin{array}{l}\text { Interprets Hammarskjöld's norms } \\
\text { entrepreneurship through the lens of } \\
\text { post-secular theory }\end{array}$ \\
\hline 12 & $\begin{array}{l}\text { Maniyalath, } \\
\text { Narendranathan; } \\
\text { Narendran, Roshni }\end{array}$ & $\begin{array}{l}\text { The human development } \\
\text { index predicts female } \\
\text { entrepreneurship rates }\end{array}$ & 2016 & $\begin{array}{l}\text { Nation's religious composition as a } \\
\text { significant determinant of female total } \\
\text { entrepreneurial activity }\end{array}$ \\
\hline 13 & $\begin{array}{l}\text { Wiseman, Travis; } \\
\text { Young, Andrew }\end{array}$ & $\begin{array}{l}\text { Religion: productive or } \\
\text { unproductive? }\end{array}$ & 2014 & $\begin{array}{l}\text { Religious belief and belonging tend to } \\
\text { correlate negatively and significantly } \\
\text { with a state's productive } \\
\text { entrepreneurship score }\end{array}$ \\
\hline 14 & $\begin{array}{l}\text { Aygun, Zahide } \\
\text { Karakitapoglu; Arslan, } \\
\text { Mahmut; Guney, Salih }\end{array}$ & $\begin{array}{l}\text { Work values of Turkish and } \\
\text { American university students }\end{array}$ & 2008 & $\begin{array}{l}\text { Highly religious participants reported } \\
\text { greater protestant work ethic scores } \\
\text { than the less religious ones } \\
\text { regardless of culture }\end{array}$ \\
\hline
\end{tabular}

\section{Discussion, Future Research Directions, and Conclusions}

This study depicts a review of published work on religiosity and entrepreneurship by means of content and descriptive analysis of articles. Authors used highly-ranked papers for the analysis. In order to extract relevant papers, authors used keywords to find relevant studies from the Web of Science database. After searching papers, authors performed initial screening by reading title, abstracts, introductions and conclusions. After the screening, papers were excluded those did not meet the inclusion criteria. For instance, at first, selected paper should cover the Social Science Citation Index, Science Citation Index and Arts \& Humanities Citation Index. Second, papers should be related to religiosity and entrepreneurship. Third, papers should be published in the ISI and Scopus Index journals. In conquering of this, authors analyzed 14 papers those met the inclusion criteria.

Authors used Web of Science database to present review on 14 papers because of relevance of content matches with objective of this study. As per statistics mentioned in this study, future research interest is to identify the dimensions of religiosity and measure their direct and indirect influence on entrepreneurship. Empirical research that examine the religiosity aspect in determining the entrepreneurial activity, attitude, intention and behavior remains insufficient, and, therefore, unable to make a strong argument when it based on the believing, behaving belonging and bonding (Hoogendoorn et al., 2016). This will support future researchers belong to social and business management field, to define religiosity based on the values and religion in cultural settings, to measure religiosity based on the practices and beliefs and to develop universal measurement scale for religiosity. Accordingly, this paper provides knowledge through systematic review in the area of 
religiosity and entrepreneurship in order to suggest future research. With support of systematic review method, this study identified the main role of religiosity for the case of Muslim entrepreneurs as compare to the non-Muslim. Indeed, these findings are not concrete unless to conduct the comparative study on religiosity preferences for entrepreneurs in several countries.

The relationship between religion and entrepreneurship is by nature an intricate one. The studies reviewed under this section show that there is relatively a sizable amount of scholarly works conducted on the relationship between religious faith and entrepreneurship. However, a great deal of these studies has been conducted in the context of Western Christian societies and very few were found in relation to other religious faiths such as Hinduism, Buddhism, and other famous world religious faiths. The relationship between entrepreneurship and religiosity has been studied by some scholars in various social contexts. Likewise, in the case of Islam a few studies have looked at the relationship between the two and to what extent one influences the other taking into consideration social and environmental contexts. It is along these lines that Kayed (2006) examined the relationship between Islamic values and entrepreneurial activities and make a case on whether the values can be used in raising the profile of Islamic version of entrepreneurship that may promote alternative development. The study found that there was not any evidence of lack of incompatibility between Islamic values and entrepreneurship. Another finding made by the study showed that irrespective of demographic backgrounds and physical attributes of their enterprises, have positive attitudes and perceptions towards the role of Islamic values towards promoting productivity with the aid of entrepreneurship.

The role of Islam in the entrepreneurial behavior of its followers has also been given attention by Davis (2013) that examined the role Islam plays in the entrepreneurial behavior of its adherents. The study argued that Islam does not necessarily and directly promote entrepreneurial behavior. However, Islam promotes, teach, and propagate cultural value systems which include, among many other social life aspects, business, entrepreneurship, and commercial dealings among its adherents. This was evident as Islam right from the outset was tied to entrepreneurship given the fact that the first wife of the Prophet Muhammad, Khadija bint Khuwaylid, was a merchant or even an entrepreneur in her own right. Her wealth supported the Prophet's mission and helped in spreading the message of Islam, particularly in its formative years. The study concluded that the combination of reality and certain verses from the Qur'an which encourage self-sufficiency and entrepreneurial behavior should propel Muslims into engaging in ventures and the creation of new enterprises in their quest to support self and the entire community at large.

Gümüsay (2015) argued that the relationship between Islam as a faith and entrepreneurship is based on three interconnected pillars which include the entrepreneurial, socio-economic/ethical, and religio-spiritual. The study further argued that Islam as a faith shapes entrepreneurship at the micro-, meso-, and macro level and that Islam can be considered as an entrepreneurial religion for the fact that it enables and encourages its followers for entrepreneurial activities. In addition, religion tends to direct people towards different business options. Muslims choose certain type of business whereas Christians also tend to prefer certain type of businesses. Related literature suggests that religion affects individuals' perception about desirability or undesirability of entrepreneurial activities and the role of entrepreneurs in society (Abdullahi and Suleiman, 2015). According to Max Weber's school of thought, religiosity is the main driving force behind entrepreneurship because people are product of religious values (Weber, 1992). This is in line with the findings of Henley (2017) stating that religiosity significantly impacts entrepreneurship. Though scholars have agreed that religion influences entrepreneurship (Rietveld and Burg, 2014), there is still debate on how and in which way religious values impact entrepreneurship.

In this sense, the current study provides a multidisciplinary stream of research related to religiosity and entrepreneurship and opens a future research avenue to explore attribute and preferences of religiosity in entrepreneurship discipline. Table 3 depicts the future research studies referred by authors from selected published studies. Furthermore, it will be possible to conduct more comprehensive studies from an integrated perspective of social sciences, managerial and behavioral issues. 
Table 3. Recommendations of future study by previous scholars

\begin{tabular}{|c|c|c|}
\hline No & Author & Recommendations \\
\hline 1 & Woodside et al (2020) & $\begin{array}{c}\text { Examine religiosity as a dimension of culture for entrepreneurship } \\
\text { development }\end{array}$ \\
\hline 2 & Toledano (2019) & Influence of religiosity and spirituality in the entrepreneurial process \\
\hline 3 & Daou et al (2019) & Role of religion and faith in entrepreneurship \\
\hline 4 & Aman (2019) & $\begin{array}{c}\text { Measure relationship between religiosity and the socio-cultural for } \\
\text { tourism entrepreneur development }\end{array}$ \\
\hline 5 & Craciun (2019) & Religious appropriateness for merchandise entrepreneurship \\
\hline 6 & Liu et al (2018) & Association among religion, creativity and entrepreneurship \\
\hline 7 & Baranik et al (2018) & Relationship between religiosity and entrepreneur performance \\
\hline 8 & Blankson et al (2018) & $\begin{array}{l}\text { religiosity-infused culture, social networks and entrepreneurial } \\
\text { business performance }\end{array}$ \\
\hline 9 & Gursoy et al (2017) & $\begin{array}{l}\text { Examine impact of Level of religiosity on attitudes and behaviors } \\
\text { towards social responsibility practices }\end{array}$ \\
\hline 10 & Dionigi (2016) & Religiosity as a resource and a driving force for entrepreneurship \\
\hline 11 & Maniyalath and Narendran (2016) & $\begin{array}{l}\text { Religious composition with human development and female } \\
\text { entrepreneurship }\end{array}$ \\
\hline 12 & Hoogendoorn et al (2016) & Entrepreneurship values relatedness with religion \\
\hline 13 & Wiseman and Young (2014) & $\begin{array}{l}\text { Religiosity and levels of entrepreneurial activity either productive or } \\
\text { not. }\end{array}$ \\
\hline 14 & Aygun et al (2008) & Individual's perceptions of religiosity and entrepreneurship \\
\hline
\end{tabular}

\section{References}

1. Abdullahi, A. I. and Suleiman, M. S. (2015) 'Impact of Religion on Entrepreneurial Intention of University Students in Kano State, Nigeria', in International Conference on Empowering Islamic Civilization in the 21st Century, pp. 363-375.

2. Adamu, I. M. and Mansur, M. S. (2018). An Overview of Entrepreneurial Motivation from the Perspective of Developing World. GOUni Journal of management and social sciences, 4(2), 250-262.

3. Aman, J., Abbas, J., Mahmood, S., Nurunnabi, M., \& Bano, S. (2019). The influence of Islamic Religiosity on the perceived socio-cultural impact of sustainable tourism development in Pakistan: A Structural equation modeling approach. Sustainability, 11(11), 3039.

4. Audretsch, D. B., \& Belitski, M. (2013). The missing pillar: the creativity theory of knowledge spillover entrepreneurship. Small Business Economics, 41(4), 819-836.

5. Aygün, Z. K., Arslan, M., \& Güney, S. (2008). Work values of Turkish and American university students. Journal of Business Ethics, 80(2), 205-223.

6. Baranik, L. E., Gorman, B., \& Wales, W. J. (2018). What makes muslim women entrepreneurs successful? A field study examining religiosity and social capital in Tunisia. Sex Roles, 78(3-4), 208219.

7. Baharun, R. and Kamarudin, S. (2001). The effects of entrepreneurs' personal religious values and business performance in information technology industry, Journal of Enterprising Culture, Vol. 9, No. 4, pp. 437-448

8. Blankson, C., Cowan, K., \& Darley, W. K. (2018). Marketing practices of rural micro and small businesses in Ghana: The role of public policy. Journal of Macromarketing, 38(1), 29-56.

9. Crăciun, M. (2019). A Seller's Sincerity: The Fashionably Veiled Designer-Entrepreneur in Turkey. Ethnos, 84(3), 415-435.

10.Damiano, R. F., de Andrade Ribeiro, L. M., dos Santos, A. G., da Silva, B. A. and Lucchetti, G. (2017) 'Empathy is Associated with Meaning of Life and Mental Health Treatment but not Religiosity 
Among Brazilian Medical Students', Journal of Religion and Health. Springer US, 56(3), pp. 10031017.

11.Daou, A., Joseph, J., Yousif, D. S., Fathallah, R., \& Reyes, G. (2019). Intellectual capital and resilience in torn societies. Journal of Intellectual Capital.

12.Davis, M. K. (2013). Entrepreneurship: an Islamic perspective. International Journal of Entrepreneurship and Small Business, 20(1), 63-69.

13.Deller, S. C., Conroy, T. and Markeson, B. (2018) 'Social capital, religion and small business activity', Journal of Economic Behavior and Organization. Elsevier B.V., 155, pp. 365-381.

14.Deutschmann, C. (2003) 'Capitalism as a Religion? An Unorthodox Analysis of Entrepreneurship', European Journal of Social Theory, 4(4), pp. 387-403.

15.Dionigi, F. (2016). Dag Hammarskjöld's Religiosity and Norms Entrepreneurship: A Post-secular Perspective. Politics and Religion, 9(1), 162-186.

16.Faizal, P. R. M., Ridhwan, A. A. M. and Kalsom, A. W. (2013) 'The Entrepreneurs Characteristic from al-Quran and al-Hadis', International Journal of Trade, Economics and Finance, 4(4), pp. 191-196.

17.Gümüsay, A. A. (2015). Entrepreneurship from an Islamic perspective. Journal of Business Ethics, 130(1), 199-208.

18.Gursoy, D., Altinay, L., \& Kenebayeva, A. (2017). Religiosity and entrepreneurship behaviours. International Journal of Hospitality Management, 67, 87-94.

19. Henley, A. (2017) Does religion influence entrepreneurial behaviour?, International Small Business Journal: Researching Entrepreneurship.

20.Higgins, J.P. and Green, S. (2008) Cochrane Handbook for Systematic Reviews of Interventions; Wiley Online Library: Hoboken, NJ, USA.

21. Hoogendoorn, B., Rietveld, C. A., \& van Stel, A. (2016). Belonging, believing, bonding, and behaving: the relationship between religion and business ownership at the country level. Journal of evolutionary economics, 26(3), 519-550.

22.Iddagoda, Y. A., \& Opatha, H. (2017). Religiosity: Towards A Conceptualization and An Operationalization. Sri Lankan Journal of Human Resource Management, 7(1).

23.Kamarudin, S., Baharun, R., Abdullah, R. T., and Liaw, J. O. H., (2013) Religious faith and its effect on entrepreneurship values, marketing and human resource strategy and business performance: An empirical analysis, Proceedings of $5^{\text {th }}$ International Conference on Humanities and Social Sciences, $\left(27^{\text {th }}\right.$ April 2013)

24.Khan, N., \& Qureshi, M. I. (2020). A systematic literature review on online medical services in Malaysia. International Journal of Online and Biomedical Engineering, 16(6), 107-118. https://doi.org/10.3991/ijoe.v16i06.13573

25.Kayed, R. (2006). Islamic entrepreneurship: A case study of the Kingdom of Saudi Arabia. (Doctorate dissertation), Massey University, New Zealand.

26.Liu, Z., Guo, Q., Sun, P., Wang, Z., \& Wu, R. (2018). Does Religion Hinder Creativity? A National Level Study on the Roles of Religiosity and Different Denominations. Frontiers in psychology, 9, 1912.

27. Maniyalath, N., \& Narendran, R. (2016). The human development index predicts female entrepreneurship rates. International Journal of Entrepreneurial Behavior \& Research.

28.Neal, J. (2013) Handbook of Faith and Spirituality in the Workplace: Emerging Research and Practice, Tyson Center for Faith and Spirituality in the Workplace, Walton College of Business.

29. Rietveld, C. A. and Burg, E. Van (2014) 'Religious beliefs and entrepreneurship among Dutch protestants', International Journal of Entrepreneurship and Small Business, 23(3), p. 279.

30.Ritchie, H. A. (2016) 'Unwrapping Institutional Change in Fragile Settings: Women Entrepreneurs Driving Institutional Pathways in Afghanistan', World Development. Elsevier Ltd, 83, pp. 39-53.

31.Toledano, N. (2019). Looking for god, meaning, physical fitness and beyond: the religious and spiritual space in sport entrepreneurship. International Entrepreneurship and Management Journal, 1-20.

32. Weber, M. (1992) The Protestant ethic and the spirit of capitalism, translated by T. Parsons. London: Routledge. 
33.Webster, J. and Watson, R.T. (2002) Analyzing the past to prepare for the future: Writing a literature review. Mis Q. 2002, xiii-xxiii.

34.Wiseman, T., \& Young, A. (2014). Religion: productive or unproductive?. Journal of Institutional Economics, 10(1), 21-45.

35.Woodside, A. G., Megehee, C. M., Isaksson, L., \& Ferguson, G. (2020). Consequences of national cultures and motivations on entrepreneurship, innovation, ethical behavior, and quality-of-life. Journal of Business \& Industrial Marketing.

36.World Bank (2020) World Bank Country and Lending Groups: Available on: https://datahelpdesk.worldbank.org/knowledgebase/articles

37./906519-world-bank-country-and-lending-groups

38.Zahrah, N., Abdul Hamid, S. N., Rani, S. H. A., and Kamil, B. A. M. (2016). Enhancing Job Performance through Islamic Religiosity and Islamic Work Ethics. International Review of Management and Marketing, 6(SI), 195-198. 